\title{
軟性下疳菌ノ生物學的站二臨彇 的研究(第三報)
}

\section{軟性下底菌 Vaccin 八臨牀的研究}

（昭和 13 年 2 月 28 日受付）

東京帝國大學傳染病研究所第七研究部(主任 矢追助教授)

研究生鈴 木 餘四郎

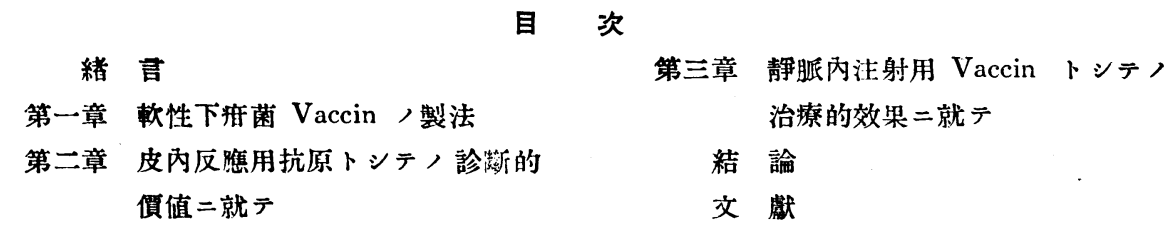

緒言

Dmelcos ノ名キモッテ知ラレテキル佛國䳤軟性下底菌 Vaccin，皮內反應用抗原

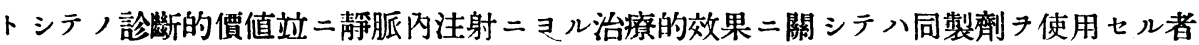
ノ妿シク認ムル所ナリ。本邦二於テモ凬二廣瀨. 遠山. 市川及ビ其他ノ諸氏ハ同製 劑ノ顯著ナル效果二關シ報告七リ。更二市川．篠田/兩氏八自家製軟性下疳菌Vaccin 于使用三彭斷的泣二治療的二效果顯著ナルモノアリト報告セり。

余八先年來軟性下将菌, 生物學的研究二從事七ル傍亏余ノ分離七ル十餘株, 軟性下

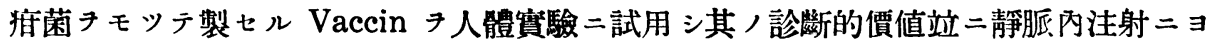
几軟性下症及ビ軟性下疷性橫痃二對スル治療的效果頗儿顯著ニシテ Dmelcos 二比 シ 豪モ遜色ナキキ認メタリ。

\section{第一草 乾性下溏菌 Vaccin ノ製法}

家鬼血液寒天 $=24$ 乃至 72 時閒培養, 數株, 軟性下府菌, 聚落尹搔キ集入生理的食

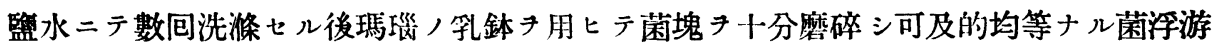

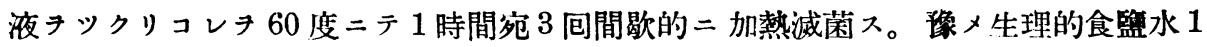

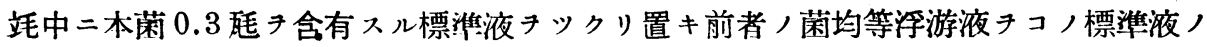


溷濁度卜同一程度二至ルマデ生理的食監水二テ稀釋シ $0.5 \%$ ，割合二石炭酸キ混入七 シメ約 2 週間水室二貯藏シ殺菌試驗後使用二供七リ。

\section{第二章 皮內反應用抗元トシテノ診断的價值二就テ}

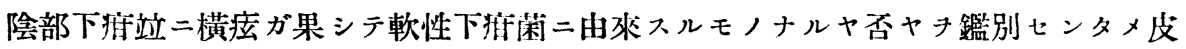
內反應用抗原トシラ軟性下痛菌 Vaccin チ使用七ルハ實二我が伊東氏二㓱マリ(伊東 氏反應). 爾來內外幾多ノ追試者ガ䂟シク其ノ卓越ヒル 診斷的價值二稱贊チ措マザル 所ナリ。

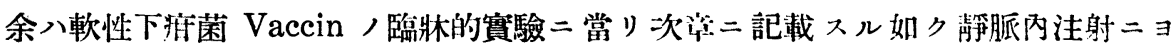
几治療的效果, 實驗卜同時二皮內反應用抗原トシテノ診断的價值二就キ實驗七り。 Vaccin 使用量八前草二記載セル抗原 0.1 竓皮內注射シ 24 時間後二觀察七り。

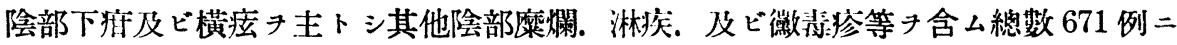
就キ實驗セル結果第 1 表二示ス如ク臨牀的二有痛性下狧 ニアリテハ 118 例中陽性 89 例 $(75.4 \%)$ チ認ム。又有痛性下痛站二横痃チ有スルモノニアリテハ 105 例中陽性 81

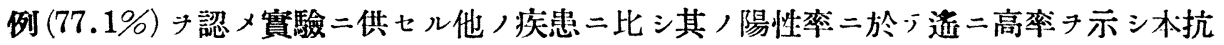
原ノ診斷的價値ノ甚ダ顯著ナルチ認メタリ。

表中反應別 (十)トアルハ浸潤ノ直徑 0.5 粝以上ノモノチ示シ反應激甚ナルモノ二於

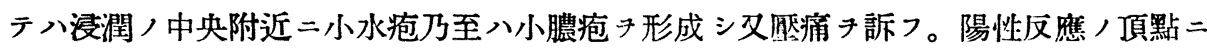
達スルニ要スル㭙間ハ必ズシモ 48 時間ニテハ霂足シ得ザルモ，、如ク．個人ニョリ テハ 72 時間ニシテ最高二達スルコトアルチモツテ制定, 萬全キ期サント欲セバ必ズ 72 時間後マデ 觀察 チ要スルモノト思惟ス。

\begin{tabular}{|c|c|c|c|c|c|}
\hline 症狀別 反應別 & + & - & 計 & $\begin{array}{l}\text { 陽分性 } \\
\text { 皇 }\end{array}$ & $\begin{array}{l}\text { 檢素 } \\
\text { 總數 }\end{array}$ \\
\hline 有 痛 性 下底 & 89 & 29 & 118 & $75.4 \%$ & \multirow{10}{*}{671} \\
\hline 無 痛 性 下疷 & 29 & 107 & 136 & $21.3 \%$ & \\
\hline 有痛性下底䈴橫疾 & 81 & 24 & 105 & $77.1 \%$ & \\
\hline 無痛性下䈴橫疼底 & 26 & 67 & 95 & $27.9 \%$ & \\
\hline 陰 部 糜 爛 & 17 & 31 & 48 & $35.9 \%$ & \\
\hline 陰部糜爛策橫瘁 & 2 & 3 & .5 & $40.0 \%$ & \\
\hline 原發病筑不明橫痘 & 4 & 12 & 16 & $25.0 \%$ & \\
\hline 子宮淋及尿道淋 & 18 & 71 & 89 & $20.0 \%$ & \\
\hline 毒 & 10 & 18 & 28 & $35.7 \%$ & \\
\hline 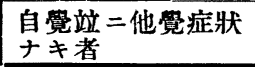 & 12 & 21 & 33 & $36.3 \%$ & \\
\hline
\end{tabular}

份木第 1 表中有痛性下痻 及ビ有痛性下㿇性横痃以外 ノ疾患ニアリテモ稍 ?高キ 陽性率き示七ルモノアルハ 恐ラク本實驗八橋本氏ノ格 別ナル御配虙卜御援助二ヨ リ東京市寺島ノ接客媂チモ ツテ施行セル・展 ナル故既 往二㓌部下狧及ビ樥痃等チ 自學七ルコトナシト言つ被 
驗者ニアリテモ接客キ業トスル者故所謂回顧現象二就キ考虑き要スルモノアリト思 惟ス。

\section{第三章 静脈內注射用 Vaccin トシテノ治療的效果ニ就テ}

原發症下㑏及ビ續發症横痃ガ臨林的所見ノてナラズ伊東氏反應或ハ細菌檢查等ニヨ

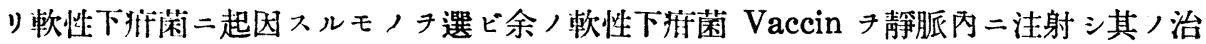
療的效果二就キ䁈驗七り。

軟性下猚菌 Vaccin 子靜脈內二注射スル時ハ 39 乃至 40 度內外，高熱發シ時二惡 感戰慄チ见ルハ同 Vaccin チ使用セル者ノ齊シク經驗七ル所ナリ。余ノVaccin二於 テモ同樣注射後啠時ニシテ 39 乃至 40 度ノ發熱ヲ見. 違和テ訴フル者多シ。個人ニヨ リ婜感戰慄キ認ムルコトアルモ悉ク一過性ノ現象ニシテ暫時ニテ止 $i$ 多クノ例二於テ 下熱後モ数時閶頭痛タ訴フルコトアリ．頭痛ノタメ一時不眠ニ陷リシ一例キ除キテハ 他二何等髠虑スベキ重篤ナル症狀キ見ズ。

余ハ洁射間隔キ隔日又ハ 2 日間隔トシ第 1 回注射量チ 0.2 乃至 0.4 浭トシテ其ノ症

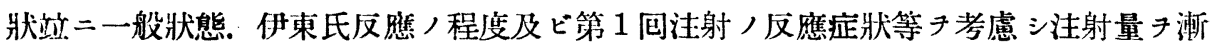
進的二增量シツ、5 乃至 7 回施行シ滿足スベキ成果キ擧ゲ得タリ。實驗例全部二就キ 熱型其他チ詳記スルノ煩チサケ次二其ノ數例二就キ記載ス。佾ホ實驗全例ノ簡單ナル 記載ハ第 5 表及ビ第 6 表二示七リ。

第 1 例 男 43 年 病名 右側軟性下症性横痃

伊東氏文應 (+)。F.R. (-)。W.R. (-)

病歷：約 1 ケ月前感染機會後數日ニシテ冠狀溝二小潰瘍き認メ疼痛タ訴フ。某醫二

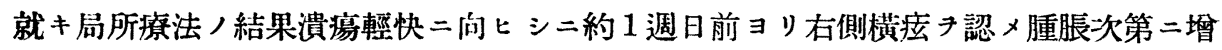

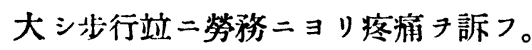

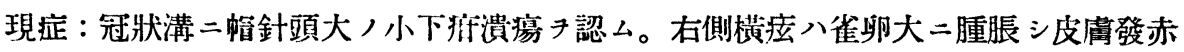

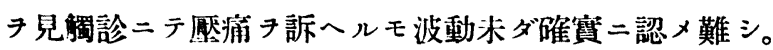

經過概要 : 余ノ軟性下谋菌 Vaccin 注射量. 注射回數及ビ發熱狀態八第 2 表熱型二 示七ル如クナルモ 注射後 2 乃至 3 時間二シテ最高 $39^{\circ} .6 \mathrm{c}$ 乃至 $39^{\circ} .4 \mathrm{c}$ 人高熱チ發シ

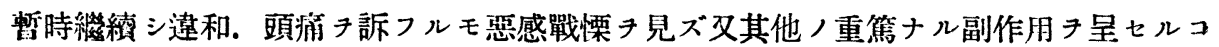
トナシ。

Vaccin 洼射 2 包ニシテ冠狀溝ノ小潰瘍全ク快癒シ橫痃モ亦發赤減シ厴痛大イ二輕

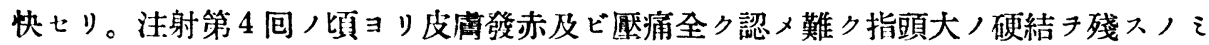


トナレリ。注射回數 7 回. Vaccin 使用全量 7.1 竜二テ軟性下狩潰瘍及ビ横㾦全ク快 癒セリ。

第 2 表 第 1 例 $\square$ 右側軟性下底性横痓

\begin{tabular}{|c|c|c|c|c|c|c|c|c|c|c|c|c|c|c|c|c|c|c|}
\hline 病 & & 1 & 2 & 3 & 4 & 5 & 6 & 7 & 8 & 9 & 10 & 11 & 12 & 13 & 14 & 75 & 16 & \\
\hline 注射 & & $0.3 c c$ & 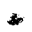 & $0.5 c c$ & & & $0.7_{C C}$ & & $1.0 \mathrm{cc}$ & & & $1.3 c c$ & & $1.5 c c$ & & & $\therefore \varepsilon_{c o}$ & \\
\hline \begin{tabular}{|l|l|}
$R$ & $P$ \\
\end{tabular} & & & & & & & & & & & & & & & & & & \\
\hline $10 \mid \begin{array}{l}100 \\
150\end{array}$ & 40 & & & & & & & & & & & & & & & & & \\
\hline $10 \begin{array}{l}100 \\
140\end{array}$ & & & & & & & & & & & & & & & & 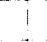 & 1 & \\
\hline $801: 30$ & 39 & & & & & & & & & & & d & & & & & $A$ & \\
\hline$\left|\begin{array}{ll}120 \\
120\end{array}\right|$ & & & & & & & & & & & & & & & & & & \\
\hline \begin{tabular}{l|l|l}
60 & 110
\end{tabular} & 38 & & & & & & & & & & & & & & & & & \\
\hline 100 & & & & & & & & & & & & & & 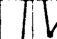 & & & & 1 \\
\hline $\begin{array}{lll}40 & 90\end{array}$ & 37 & & $L$ & & & & & & & & & & & & & & & 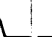 \\
\hline 80 & & & & & & & & & & & & & & & & & & \\
\hline 2070 & & & & & & & & & & & & & & & & & & \\
\hline
\end{tabular}

第 2 例 男 21 年 病名 軟性下狧溃瘍

伊東氏反應 $(+)$ 。F.R. (-)。W.R. ( - )

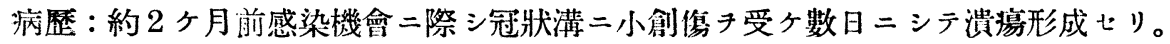
疼痛き押シテ勞務二從事スル事約 1 只後二八潰瘍面次第二增大シ龜頭後面全部二及 ブ大潰瘍トナリ勞務不能トナリ約 1 ケ月間局所的二加療子施七ルモモ快方ニ间ハザリ キ。

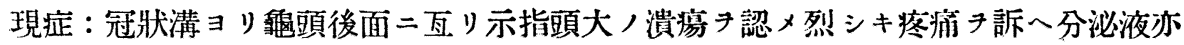
多量ナリ。

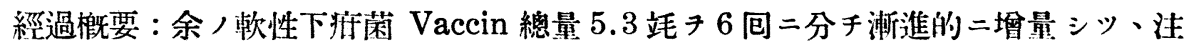
射 施行セリ。注射後數時間ニシテ 39.6 度乃至 38.9 度ノ高熱子發シ下熱後頭痛子

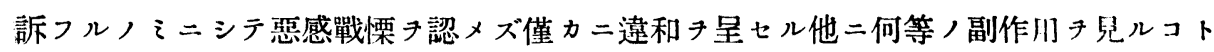
ナシ。

Vaccin 注射第 2 回ノ頃ヨリ疼痛著シク減退シ。洼射第 3 回ノ頃ヨリ溃癔面周圍 り肉芽形成著シク增進シ注射 4 回ニシテ疼痛全ク湐失シ。溃痛面ノ面積注射前ノ約 3 分， 1 二縮小七ルチ見ル。而シテ分泌液モ大 1 二減少シ注射完了後數日二シテ大溃場 モ全ク快癒七り。約 1 ケ月餘二瓦り局所的加療施セルニモ拘ラズ萑阵快グ二间ハザ リシ軟性下疷潰瘍ガ余, Vaccin 静脈內注射療法開始後僅カニ牛旬ニシテ急激ナル全 治的倾向チ示七ルョリ觀レバ本Vaccinノ治療的效果ノ顯著ナルキ知ルニ足ルベシ。 (第 3 表) 
第 3 表 第 2 例 口軟性下底性潰

\begin{tabular}{|c|c|c|c|c|c|c|c|c|c|c|c|c|c|c|}
\hline 病 日 & 1 & 2 & 3 & 4 & 5 & 6 & 7 & 8 & 9 & 10 & 11 & 12 & 13 & 14 \\
\hline 注射量 & $0.2 c c$ & & $0.6 c c$ & & & $0.8 c c$ & & $1.0 c c$ & & & $1.2 c c$ & & $1.5 c c$ & \\
\hline $\begin{array}{l:l}R & P \\
160\end{array}$ & & & & & & & & & & & & & & \\
\hline $100150 \quad 40$ & & & & & & & & & & & & & & \\
\hline 140 & & & & & & & & & & & & & & \\
\hline $\begin{array}{lll}80 & 130 & 39\end{array}$ & & & & & & & & & & & & & & \\
\hline 120 & & & & & & & & & & & & & & \\
\hline $60 \quad 11038$ & h & & & & & & & & & & & & & \\
\hline 100 & & & & & & & & & & & & & & \\
\hline 9037 & & & & & & & & & & & & & & \\
\hline & & & V & & & & & & & & & & & 4 \\
\hline $20-7036$ & 1 & & & & & & & & & & & & & \\
\hline
\end{tabular}

第 3 例

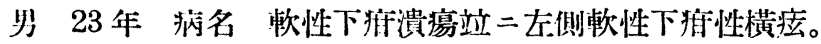

伊東氏反應(+) F.R.(一) W.R.(一)

病曆 : 約 20 日前ヨリ冠狀溝二小溃瘍子認メシモ疼痛チ自覺セザリシタメ放置シ置 ケリ。約 10 日前ヨリ溃瘍面次第二增大シ疼痛ヨ伴フ二至り。分泌液キ排出入。1週 日前ヨリ左侧横痃フ認ム。

現症 : 冠狀溝二溃瘍 認メ疼痛 訴つ。左側横应ハ小鶏卵大二腫脹シ皮膚發赤. 壓 痛甚シ。明暸ナラザレドモ僅カニ波動キ認ム。

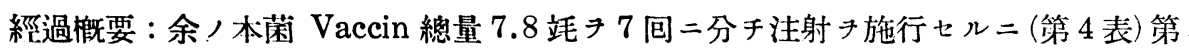

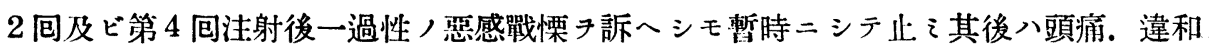
チ認メタレドモ他二何等ノ重篗ナル副作用チ見ルコトナシ。

Vaccin 注射 3 回ニシテ溃瘍殆ンド全治セり。橫痃, 發赤亦消失シ。壓痛著シク輕 減セり。注射 5 回二及ビ横痃, 腫脹著シク縮少シ發赤. 壓痛八全ク消失セり。第 7 回

第 4 表 第 3 例

軟性下底性溃瘍站二数性下底性横瘗

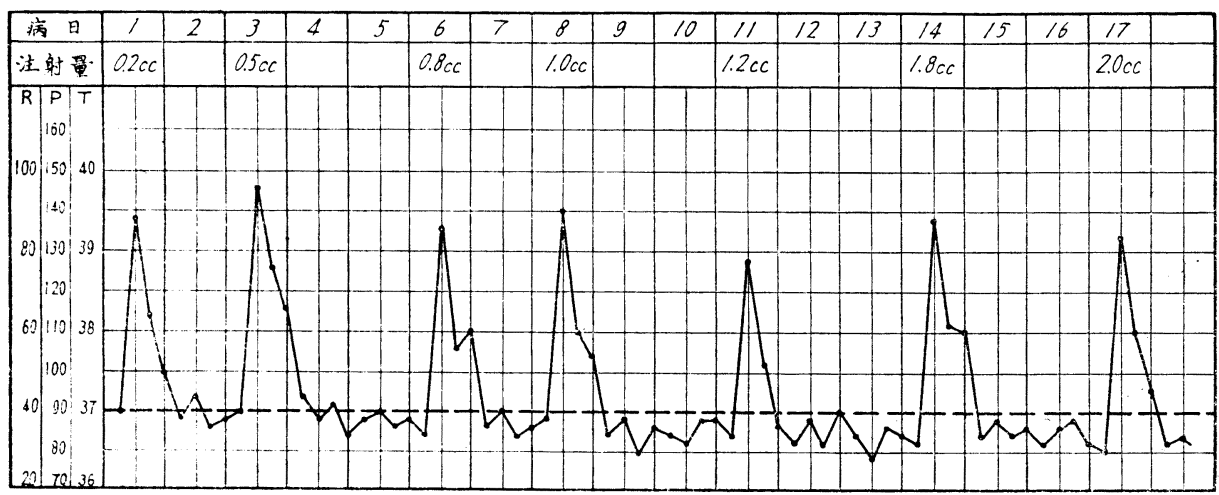


注射完了ノ頃八横痃僅っ二小指頭大ノ硬結丹殘スノミトナリ注射完了後 1 週日二再ビ 來院セシメ觸診セル二何等ノ硬結モ觸レズ全ク快瘑セリ。

第 5

表

\begin{tabular}{|c|c|c|c|c|c|c|c|}
\hline 姓 名 & \multicolumn{2}{|c|}{ 性別|年齡 } & 病 & \multicolumn{2}{|c|}{ 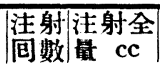 } & \multirow{2}{*}{$\begin{array}{l}\text { 經 } \\
\text { 全 }\end{array}$} & \multirow{2}{*}{$\begin{array}{l}\text { 渦 } \\
\text { 治 }\end{array}$} \\
\hline & 勇 & 27 & 軟性下痹潰痬. 左側軟性下疳性橫丧 & 5 & 3.0 & & \\
\hline & 男 & 25 & 軟性下淮潰瘍 & 5 & 3.0 & 全 & 治 \\
\hline & 男 & 23 & 軟性下底潰瘍. 右側軟性下度性橫疼 & 6 & 4.5 & 全 & 治 \\
\hline & 男 & 31 & 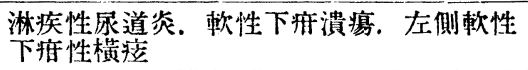 & 6 & 4.5 & \multicolumn{2}{|c|}{$\begin{array}{l}\text { 尿道淋 } \\
\text { 八殏シ他 }\end{array}$} \\
\hline & 男 & 21 & 軟性下疷潰惧 & 6 & 5.3 & 金 & 治 \\
\hline & 男 & 31 & 左側軟性下底性横㾜 & 5 & 2.5 & 全 & 治 \\
\hline & 男 & 22 & 軟性下底潰疾. 右側軟性下病性㮖㾜 & 7 & 7.8 & 全 & 治 \\
\hline & 男 & 32 & 右側軟性下疷性橫㾦 & 5 & 3.2 & 全 & 治 \\
\hline & 男 & 29 & 軟性下底潰瘍 & 6 & 4.5 & 全 & 治 \\
\hline & 男 & 31 & 左側軟性下麻性橫疼 & 6 & 2.7 & 全 & 冶 \\
\hline & 男 & 32 & 右側軟性下底性橫㾦 & 5 & 2.5 & 輕 & 快 \\
\hline & 男 & 23 & 軟性下底潰痬 & 3 & 2.5 & 全 & 治 \\
\hline & 男 & 26 & 左側軟性下底性橫㾦 & 6 & 4.5 & 全 & 治 \\
\hline & 男 & 23 & 軟性下底潰瘍. 右側軟性下底性橫疼 & 7 & 6.0 & 全 & 治 \\
\hline & 男 & 29 & 軟性下底潰痬 & 5 & 4.2 & 全 & 治 \\
\hline & 男 & 25 & 軟性下疷潰痬. 右側軟性下底性橫瘖 & 7 & 7.2 & 全 & 治 \\
\hline & 男 & 20 & 左側軟性下底性橫瘖 & 6 & 6.8 & 輕 & 快 \\
\hline & 男 & 31 & 軟性下革潰瘍 & 5 & 5.3 & 全 & 治 \\
\hline & 男 & 36 & 軟性下痒潰瘍 & 6 & 3.2 & 全 & 治 \\
\hline & 男 & 30 & 淋病性尿道炎。軟性下底潰瘍 & 7 & 5.2 & \multicolumn{2}{|c|}{ 尿道淋 ᄏ殘シ全治 } \\
\hline & 男 & 43 & 右側軟性下底性橫㾜 & 7 & 7.1 & 全 & 治 \\
\hline & 男 & 28 & 軟性下症潰瘍. 右側軟性下底性横瘖 & 6 & 4.8 & 全. & 治 \\
\hline & 男 & 25 & 左側橫瘖（鼠蹊淋巴肉芽腫症） & 10 & 7.8 & \multicolumn{2}{|c|}{$\begin{array}{l}\text { 效果ナキタメ再三 } \\
\text { 檢診, 結果第四性 } \\
\text { 病卜物明七り }\end{array}$} \\
\hline & 男 & 21 & 軟性下底潰瘍. 右侧軟性下底性橫瘖 & $\overline{4}$ & 2.5 & 全 & 治 \\
\hline & 男 & 40 & 左側軟性下底性橫瘖 & 8 & 7.3 & 輕 & 快 \\
\hline & 男 & 24 & 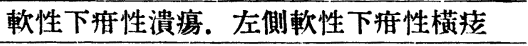 & 7 & 5.6 & 全 & 治 \\
\hline & 男 & 31 & 軟性下底性潰瘍. 左側軟性下底性橫㾜 & 6 & 5.0 & \multicolumn{2}{|c|}{ 下底全治橫瘏輕快 } \\
\hline & 男 & 36 & 右側軟性下底性橫瘗 & 6 & 5.0 & 全 & 治 \\
\hline & 男 & 20 & 左側軟性下府性橫疼、尿道淋 & 5 & 4.8 & 輕 & 快 \\
\hline & 男 & 36 & 右側軟性下底性橫瘖 & 5 & 5.6 & 全 & 治 \\
\hline & 女 & 52 & 右側軟性下底性橫洼 & 7 & 3.8 & 全 & 治 \\
\hline & 男 & 26 & 軟性下度潰瘍. 左側軟性下度性橫痴 & 7 & 4.8 & 全 & 治 \\
\hline & 男 & 26 & 軟性下底潰瘍. 左側軟性下底性橫痓 & $\overline{9}$ & 6.6 & \multicolumn{2}{|c|}{ 下底全治橫丧輕快 } \\
\hline & 男 & 35 & 左側軟性下痹性橫瘖 & 5 & 4.8 & 全 & 治 \\
\hline & 男 & 25 & 左侧軟性下席性橫瘖 & 8 & 6.6 & 全 & 治 \\
\hline & 男 & 37 & 軟性下度潰瘍. 左側軟性下疳性橫疼 & 5 & 2.9 & \multicolumn{2}{|c|}{ 下底全治橫疼輕快 } \\
\hline
\end{tabular}




\begin{tabular}{|c|c|c|c|c|c|}
\hline 男 & 28 & 右侧軟性下底性橫痓 & 7 & 3.4 & 全 \\
\hline 男 & 30 & 兩侧軟性下底性橫㷣 & 7 & 5.8 & 輕 \\
\hline 男 & 21 & 軟性下底潰㾴. 右側軟性下底性橫瘖 & 5 & 3.8 & 全 \\
\hline 男 & 23 & 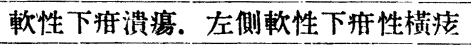 & 8 & 6.9 & 輕 \\
\hline 男 & 55 & 左側軟性下底性橫瘏 & 9 & 6.9 & 全 \\
\hline 男 & 25 & 軟性下疷潰瘍. 左側軟性下疳橫瘘 & 5 & 3.0 & 全 \\
\hline 男 & 25 & 左側橫丧 & 9 & 7.5 & 效果第四兩病 \\
\hline 男 & 32 & 右側軟性下性症橫疼 & 5 & 3.2 & 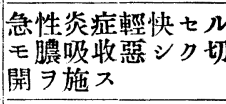 \\
\hline 男 & 29 & 軟性下底潰瘍 & 4 & 2.6 & 全 \\
\hline 男 & 31 & 軟性下㾞溃瘍. 左侧軟性下底性橫疼 & 7 & 5.8 & 全 \\
\hline 男 & 41 & 兩側軟性下㥏性橫痓 & 6 & 5.2 & 右側全治左側切開 \\
\hline 女 & 48 & 右侧軟性下疷性橫疼 & 5 & 4.0 & 全 \\
\hline 男 & 25 & 軟性下底溃㾮. 右側軟性下疷性橫瘘 & 6 & 5.2 & 下度全治橫疼切開 \\
\hline 男 & 24 & 左側軟性下度性橫瘏 & 6 & 5.8 & 全 \\
\hline 男 & 33 & 右側軟性下底性橫洼 & 6 & 5.6 & 全 \\
\hline 男 & 27 & 軟性下底潰瘍. 兩側軟性下底性橫瘗 & 4 & 3.2 & 輕 \\
\hline 男 & 28 & 軟性下度溃疗 & 4 & 3.0 & 快 \\
\hline
\end{tabular}

第 6 表

\begin{tabular}{|c|c|c|c|c|c|c|}
\hline \multicolumn{7}{|c|}{ 軟性下底菌 Vaccin 静脈內注射賽驗總數 72 例 } \\
\hline 病 & 名 & 例數 & $\begin{array}{l}\text { 本均清 } \\
\text { 射间數 }\end{array}$ & $\begin{array}{l}\text { 平均注 } \\
\text { 射量 }\end{array}$ & $\begin{array}{l}\text { 平均所要 } \\
\text { 日數 }\end{array}$ & 全治百分率 \\
\hline 下 & 底 & 29 & 5 & 3.9 & 14 & $89 \%$ \\
\hline 橫 & 瘘 & 43 & 6 & 5.0 & 18 & $63 \%$ \\
\hline
\end{tabular}

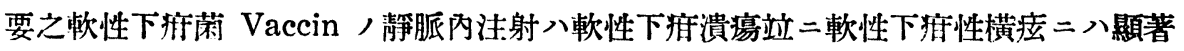
ナル效果キ有スルコト明カニシテ下谊遺瘍ハ大體 3 乃至 5 回注射二テ全治スルモノ多 ク、横痃二於テモ波動不確賽ナル初期ノモノニテハ效果確賽ニシテVaccin 注射 2 乃 至 4 回二テ發赤. 疼痛等速二消失シ腫脹亦著シク樎小スルチ見. 多クノ例二於テ注射 4 乃至 6 回二テ全治スルカ又ハ大イ二輕快スルチ認ム。既二著明ナル波動テ呈シ穿刺 二テ多量ノ排膿 見ル如キ病症ノ淮行七ル横痃ニアリテハ初期ノ横痃二比シ效果著シ カラザルテ認ムルモ仯ホV Vaccin 注射ニヨリ罹患淋巴腺周圍 ノ浸潤速 二縮小シ多少 恢復日數キ短縮セシメ得ベシ。

注射間隔八隔日又ハ 3 日目每二施行シテ何等ノ支障ナク。一過性ノ高熱キ發スルモ 心臟疾患. 㛑臟疾患等二留意シッ、注射キ行へバ必ズシモ入院キ必要ト七ズ外來患者 ニモ行ヒ得ベシ。

洼射量八第 1 回 0.2 乃至 0.3 竓 $リ$ 始 0.2 乃至 0.3 竜宛增量 テ治療ノ目的テ達シ得ベシ而シテ其ノ使用量ハ Dmelcos 二比シ遙二少量ニテ充分, 
效果き擧ゲ得。

\section{結諭}

軟性下痨菌數株チ混合セル多價 Vaccin チモッテセル皮內反應用抗原八臨牀的二軟

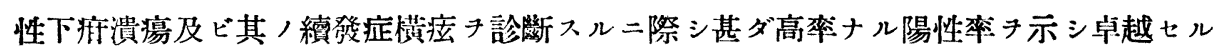
診断的價値手有七り。

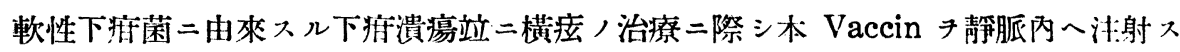
ル時ハ下狩潰瘍ニアリテハ注射回數 4 乃至 5 回. 洼射總量 3.0 乃至 6.0 竓キモッテ約 2 週日ニシテ全治又ハ快力二向ハシメ得心゙ク. 横应ニアリテハ注射回數 5 乃至 7 回. 注射總量 4.0 乃至 7.0 靖二テ全治又八著シキ全的治傾间二至ラシムルチ得べシ。郎チ 軟性下瘦潰瘍ニトリテハ他, 局所的療法二比シ遙二優秀ナルノネナラズ. 軟性下㾈性 橫痃ニトリテモ其ノ初期ノモノニテハ殆ンド外科的處置き施サズシテ而モ從來ノ療法 二比シ著シク恢復日數キ短縮七シメ得べシ。

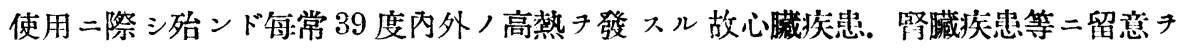
要スルハ刎諭ナレド注射後頭痛或八時ニ一過性，惡感戰慄き呈スルコトアルモ其他，

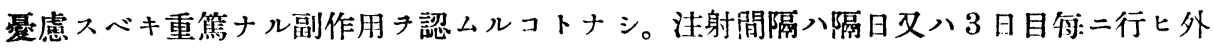
來患者ニテモ支障ナク施行可能ナリ。

使用量ハ症狀站二個人ノ訴へニョリ適當二增減シテ用フルキ可トスルモ Dmelcos 二比シ檤二少量ニテ充分ナル效果テ擧ゲ得ベシ。

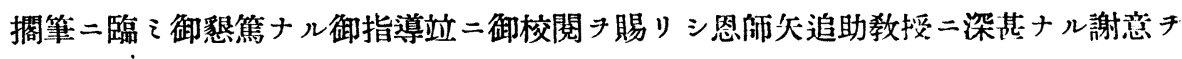

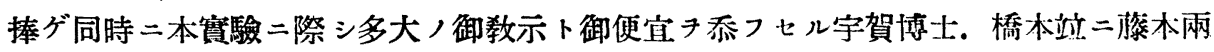
氏ニ深ク謝意キ表ス。

\section{主要文獻}

1) Nicolle, Durand, Arch. de L'Inst. Past. de Tunis. 1924.

2) Massias, Sté. med. chir. d'Judochine. 1925.

3) Nicolas, Lacassagne, Alcalay. Bull. de la Sac. France. de Dermat. \& Syph. 1926.

4) De Grave. Bruxelles Medical. 1926.

5) Nicolas, Lacassagne: Reunion. Derm. de Strasbourg. 1928.

6) Reenstierna, Arch. de L'Inst. Past. de Tunis. 1933.

7）野方次郎，海軍々醫會雜誌. 25. 1936.

8）市川. 篠田, 體性. 22-23. 1937.

9) 櫻根. 竹田, 東京醫事新誌. No. 3045, 1937. 